JOURNAL OF ENGINEERING SCIENCES

ЖУРНАЛ ІНЖЕНЕРНИХ НАУК

ЖУРНАЛ ИНЖЕНЕРНЫХ НАУК

Web site: http://jes.sumdu.edu.ua

DOI: $10.21272 /$ jes.2019.6(1).d3

Volume 6, Issue 1 (2019)

UDC 539.41

\title{
Computer-Aided Design of Prophylactic Metal Reinforcement of the Proximal Femur
}

\author{
Savielieva O. ${ }^{1}$, Starushkevych T. ${ }^{2}$, Matveev, A. ${ }^{3}$ \\ ${ }^{1}$ South Ukrainian National Pedagogical University named after K. D. Ushynsky, \\ 26 Staroportofrankivska St., 65020 Odessa, Ukraine; \\ ${ }^{2}$ Odessa National Polytechnic University, 1 Shevchenka Av., 65044 Odessa, Ukraine; \\ ${ }^{3}$ Novokujbyshevsk City Central Hospital, 32 Ostrovskogo St., 446206, Novokujbyshevsk, Russia
}

\section{Article info:}

Paper received:

The final version of the paper received:

Paper accepted online:
*Corresponding Author's Address:

November 25, 2018

January 31,2019

February 5, 2019

\begin{abstract}
Hip fractures are among the most dangerous fractures, because they are quite common in older people and are difficult to treat. Based on the general opinion, the most effective tactic is surgical treatment, but its results against the background of osteoporosis are not satisfactory. Reducing the likelihood of hip fractures is a complex problem that can only be solved by combining the idea of medical science and mechanical research of a deformable solid. In this paper, the calculation of stresses arising from exposure to the reinforced femur neck of various loads is considered. At the current stage of the study, calculations of the stress-strain state corresponding to the loads at the moment of impact when a person falls on the thigh are carried out. Comparison of the values of withstanding stresses indicates the utility of using the considered implants, which in consequence will reduce the likelihood of a hip fracture. Using reinforcing metal structures in the bone has led to increasing of the highest extremes by about $140 \%$, which confirms the utility of their use. Thus, pre-reinforcement of the femoral neck in elderly people at risk reduces the likelihood of fracture due to the reduction of critical stresses in hazardous areas.
\end{abstract}

Keywords: numerical simulation, femur neck, mathematical modeling, deflected mode.

\section{Introduction}

Three-dimensional modeling allows obtaining the necessary information to study the mechanical compatibility of the implant with the bone, which determines the ability of body systems to adapt and function correctly in a new biotechnical system. By analyzing the loads, it is possible to calculate whether the design of the implant, its material and placement in the bone are successful.

The relevance of the topic is to use three-dimensional models of original designs of implants and prostheses in studying the effect of these structures on the strength of the femur.

The aim of the work is to develop various types of implants and to study, with the help of stress simulation, their effect on the resistance of the proximal femur.

The tasks of the work are to develop three-dimensional models of new implants, create three-dimensional models of various "bone - implant" systems, simulate the loads for each system, analyze the results and draw a conclusion on the use of implants.

\section{Literature Review}

Among all the fractures of the lower extremity, one of the leading places is occupied by fractures of the proximal femur, which lead to hypostatic functional disorders, "sliding" syndrome of state decompensation and high mortality (41-67\%) [1].

Fractures of the proximal femur are pathological fractures, as they are a consequence of the structural failure of the bone in osteoporosis, much less often in tumors accompanied by dystrophic and dysplastic processes in the bones [2, 3].

From $75 \%$ to $90 \%$ of persons with abnormal bone fractures due to osteoporosis are not examined, and are not treated by specific pharmacotherapy after low-energy bone fractures of different localizations [4].

The occurrence of pathological fractures of the proximal femur and femoral neck in older individuals remains an unsolved problem, which is associated with the structural failure of the bone in degenerative-dystrophic skeletal diseases. So far, the treatment of osteoporosis in the elderly has not been developed, which could actually prevent the occurrence of pathological fractures [5]. The 
weakening of the bone tissue to critical values is an indication for the prophylactic use of fixers in certain parts of the skeleton [6-8]. The method of femoral neck prophylactic reinforcement in endoprosthetics of the contralateral limb reduces the risk of new femoral neck fractures in the elderly. Prevention of contralateral fractures significantly reduces the cost of treating patients. In elderly with fractures, prophylactic reinforcement is shown from the opposite side, which undoubtedly requires a deeper study of the long-term effects $[9,10]$. To solve the above problems, the method of metal structures preventive implantation - preventive reinforcement - is successfully used in many countries [11-14].

\section{Research Methodology}

\subsection{The bone creating}

The task of holding prophylactic reinforcement is the need to strengthen specifically the femoral neck, while increasing its strength due to reinforcing metal structures. The blood circulation of the proximal, cervical and femoral head is such that when fractures of the cervix take place, a very serious impairment of blood circulation occurs, which ultimately leads to destruction, and, consequently, to aseptic necrosis - death - to the femoral head. This forces the traumatologist - orthopedic surgeon to carry out endoprosthetic replacement of the entire hip joint. For many old people, this becomes a death sentence, since $50 \%$ of these patients die in the first year after the injury. The idea of reinforcing the femoral neck is aimed at preserving it and, most importantly, preserving the life of the patient. The complex geometric structure of the bone requires sufficiently accurate measurements to build a computer model. In order to bring the calculations and construction of implants for the required level of detail, it was decided to build a bone model by extracting a three-dimensional model from a computed tomography image and transforming, using polygonal modeling, into a model that is convenient to work with.

\subsection{The implant creating}

Four types of the implants have been patented and designed for the reinforcement of biological composite material and prevention of femoral neck fractures in patients who belong to risk groups. Telescopic implants are presented in corkscrew and auger versions (Figure 1). Spoke implants are presented in the version with diverging spokes and in the version with crossed ones (Figure 2). Endoprostheses are presented in the version with a needle and in the version with a plate (Figure 3 ). Also two simple version of the implants were considered - only the spoke - auger and only the spoke - corkscrew (Figure 4). The objective of these implants is to minimize the likelihood of fracture not only of the cervix, but also of the vertical region of the femur, primarily in elderly patients who suffer from destructive - degenerative diseases of the bone tissue. This task is solved by introducing the implant in the unaffected proximal femur to increase its strength.

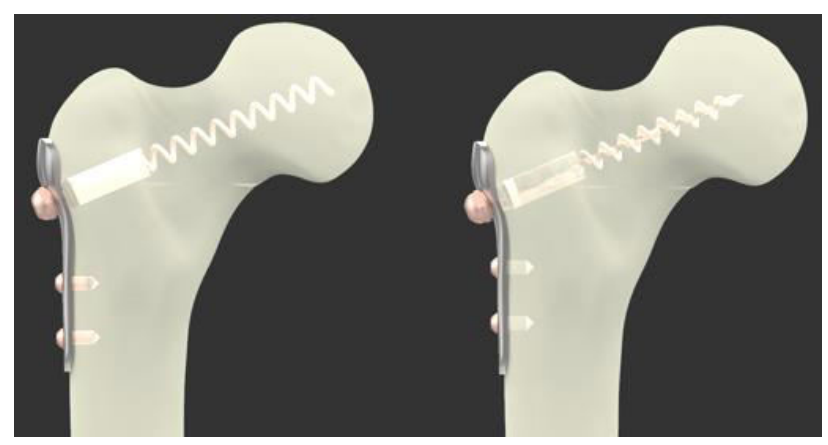

Figure 1 - Image of the bone-implant system with telescopic implants

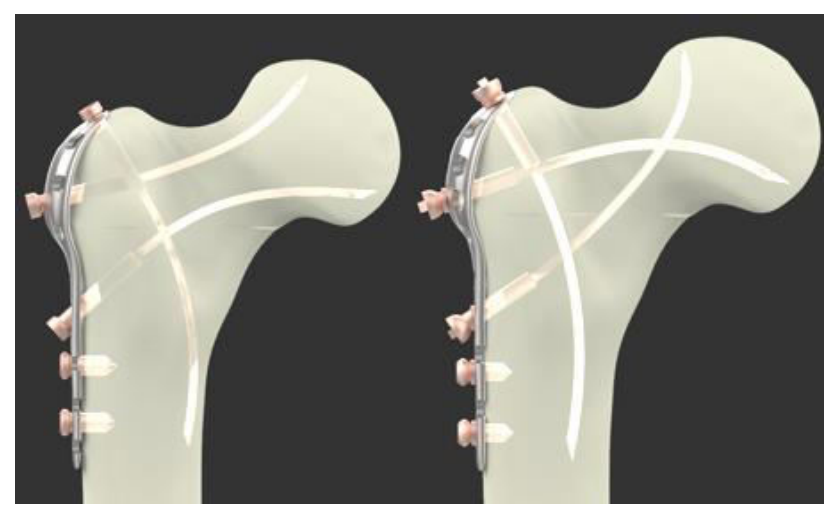

Figure 2 - Image of the bone-implant system with spoke implants

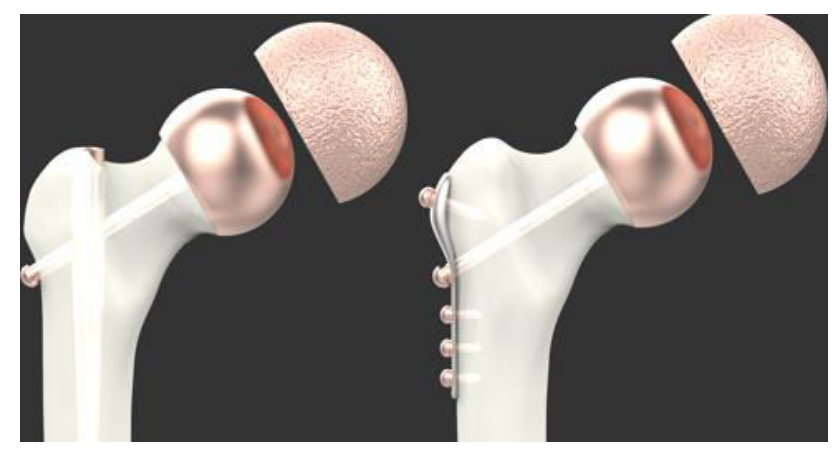

Figure 3 - Image of the bone-implant system with endoprostheses

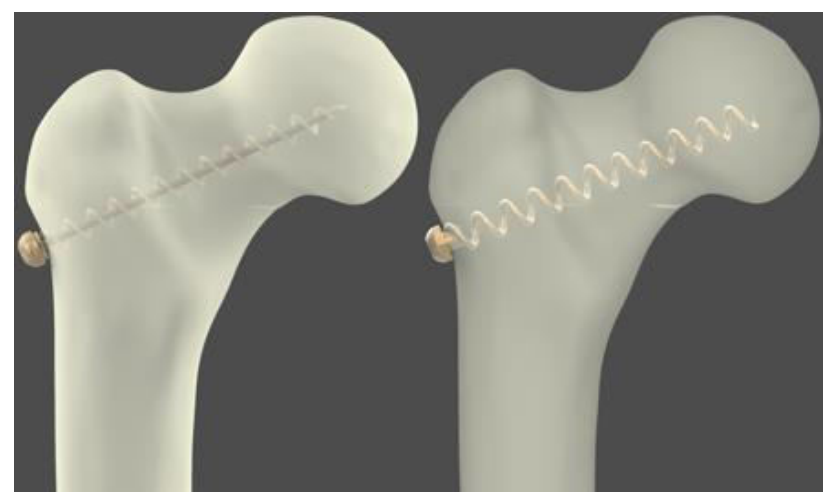

Figure 4 - Image of the system "bone - implant" with a spoke -auger and a spoke - corkscrew 
Mathematical modeling of stress conditions. The study of stressed sections of elastic deformation arising under the load of intact and reinforced bone is carried out using the finite element method and by means of mathematical modeling.

For mathematical modeling of stress conditions, the following types of loads were selected (Figure 5): vertical (fixation of the knee joint, application of load vertically to the head of the femur), horizontal (fixation of the knee joint and large trochanter, application of loads horizontally to the head of the femur) and rotational (fixation of the femoral head bones, application of torque to the diaphysis part of the bone).It is these states that most clearly demonstrate the imitation of actions leading to a fracture of the femoral neck.

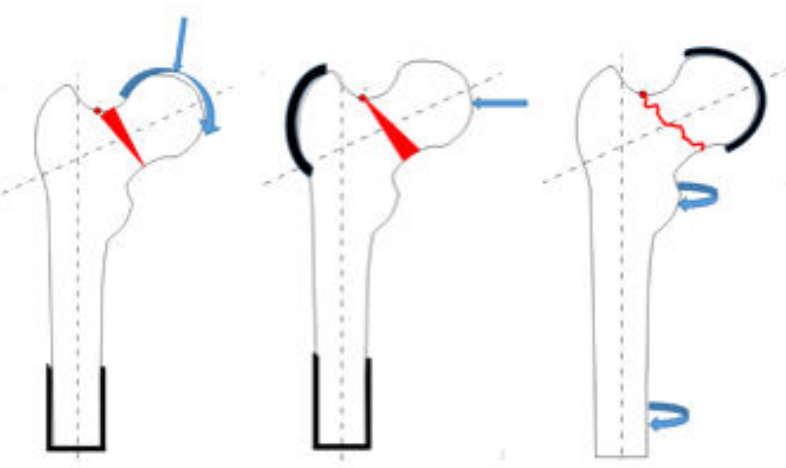

Figure 5 -The purpose of the areas of fixation and application of the load: vertical, horizontal and rotational
As a load application, a force of $700 \mathrm{~N}$ was chosen, which is equal to an action of $70 \mathrm{~kg}$.

Physical indicators of materials used in the calculations of stress conditions are presented in Table 1 .

Mathematical modeling of stress states was carried out in the Ansys Workbench software package. In each of the studies, according to the above situations of loads, the area of fixation and application of loads is indicated, as the strength of the load, and the simulation of stress states is carried out.

\section{Results}

The results of mathematical modeling are noted in Table 2.

As can be seen from the table of results, when metal structures are used in prophylactic reinforcement, the maximum load increases, which implies that the reinforced bone can withstand the effects of a fall, saving the patient from a hip fracture. This proves that reinforcement has a positive effect on increasing the strength characteristics of the bone and leads to its preservation from destruction under critical loads. Through the use of reinforcing steel, reduced stress - deformed condition of the bone.

Table 1 - Physical and mathematical indicators of materials

\begin{tabular}{|l|c|c|c|c|c|}
\hline \multicolumn{1}{|c|}{ Material } & $\begin{array}{c}\text { Density, } \\
\mathrm{kg} / \mathrm{m}^{3}\end{array}$ & $\begin{array}{c}\text { Young's } \\
\text { modulus, } \\
\mathrm{GPa}\end{array}$ & $\begin{array}{c}\text { Poisson's } \\
\text { ratio }\end{array}$ & $\begin{array}{c}\text { Tensile strength } \\
\text { limit, MPa }\end{array}$ & $\begin{array}{c}\text { Compressive } \\
\text { strength } \\
\text { limit, MPa }\end{array}$ \\
\hline Bone & 1750 & 16.7 & 0.31 & 43.44 & 115.3 \\
\hline Ti-6Al-4V & 4500 & 120.0 & 0.32 & 993.0 & 1086.0 \\
\hline
\end{tabular}

Table 2 - Physical and mathematical indicators of materials

\begin{tabular}{|l|c|c|c|}
\hline \multicolumn{1}{|c|}{ Implant type } & $\begin{array}{c}\text { Vertical, } \\
\%(\mathrm{MPa})\end{array}$ & $\begin{array}{c}\text { Horizontal, } \\
\%,(\mathrm{MPa})\end{array}$ & $\begin{array}{c}\text { Rotational, } \\
\%(\mathrm{MPa})\end{array}$ \\
\hline Bone & $100.0(16.5)$ & $100.0(2.8)$ & $100.0(0.5)$ \\
\hline Telescopic corkscrew & $162.4(26.8)$ & $164.2(4.6)$ & $196.3(0.98)$ \\
\hline Telescopic auger & $153.3(25.3)$ & $159.2(4.5)$ & $184.1(0.92)$ \\
\hline Corkscrew & $107.9(17.8)$ & $110.2(3.1)$ & $140.0(0.73)$ \\
\hline Auger & $107.5(17.7)$ & $128.4(3.5)$ & $128.0(0.64)$ \\
\hline Cross spokes & $120.1(19.8)$ & $126.7(3.4)$ & $122.2(1.61)$ \\
\hline Diverging needles & $117.6(19.4)$ & $119.2(3.3)$ & $124.2(0.62)$ \\
\hline Kernel & $129.7(21.4)$ & $182.1(5.1)$ & $150.0(0.8)$ \\
\hline Plate & $112.1(18.5)$ & $175.1(4.9)$ & $148.2(0.74)$ \\
\hline
\end{tabular}




\section{Conclusions}

With the help of mathematical modeling of stress states, the useful effect of using the original developed reinforcing metal structures was proved.

Consequently, this theoretical study can serve as a justification from the position of the mechanics of a deformable solid body with the method of hip fractures prevention due to preliminary, prophylactic, reinforcement.

In the future, as a result of the repeated positive result of the stresses in the "bone-implant" system calculation, experimental models will be produced, which will undergo bench tests. If, as a result of tests, the usefulness of the application of these metal structures is confirmed, they will be used for preventive reinforcement.

The task of the follow-up study is to prove the practicality of reinforcing the material of the bone tissue of the femoral neck in the elderly at risk. These studies are necessary because this procedure reduces the likelihood of fracture, due to the reduction of critical stresses in hazardous areas by transferring part of the load to the reinforcement element.

\section{References}

1. Lazarev, A. (2012). Operative treatment of the proximal femur fractures. VIII Congress of Traumatologists-Orthopedists of Uzbekistan "Actual Questions of Traumatology and Orthopedics", pp. 153-154.

2. Zorya, V. (2016). Treatment and prevention of fractures of the femoral neck in elderly and senile patients. Organizational and Clinical Issues of Rendering Assistance to Patients in Traumatology and Orthopedics, pp. 34-36.

3. Matveev, A. (2008). Operative way of prevention of femoral neck fractures. Patent No. 2316280, Russian Federation, IPC 7 A61B 17/56, applicant and patent owner: Matveev, A. L., No. 2006114271/14; claimed 26.04.2006; published 10.02.2008, bulletin No. 4.

4. Kotelnikov, G., Bulgakova, S., \& Shafieva, I. (2012). Evaluation of the effectiveness of a set of measures for the prevention of fractures - markers of osteoporosis in elderly women. $V$ Conference with international participation "The problem of Osteoporosis in Traumatology and Orthopedics", pp. 72-73.

5. Kochish, A., Ivanov, S., \& Sannikova, E. (2013). Comparative analysis of adherence to the diagnosis and treatment of osteoporosis in patients with low-energy fractures. VRussian Congress on Osteoporosis and Other Metabolic Skeletal Diseases, pp. 45 50.

6. Povoroznyuk, V. (2005). Osteoporosis - The Problem of the XXI Century. The Art of Treatment.

7. Faucett, S., Genuario, J., Tosteson, A., \& Koval, K. (2010). Is Prophylactic Fixation a Cost-Effective Method to Prevent a Future Contralateral Fragility Hip Fracture? Journal of Orthopedic Trauma, pp. 65-74.

8. Dimitrienko, Yu. (2011). Modelling of Mechanical Properties of Composite of 3D orthogonal woven composites. Composites Science and Technology, Vol. 71, pp. 1777-1788.

9. Zacherl, M., Gruber, G., Glehr, M., Ofner, P., Radl, R., Greithbauer, M., Vecsei, V., \& Windhager R. (2011). Surgery for pathological proximal femoral fractures, excluding femoral head and neck fractures. Resection vs. Stabilization. Department of Orthopedic Surgery, Medical University Graz, (SICOT), Austria, pp. 1537-1543.

10. Tonkonogiy, V., Savel'eva, O.,\& Bets, A. (2012). Information technology in education, science and production. Collection of Scientific Works, Bakhava JSC, Vol. 1(2), pp.182-188.

11. Kanis, J., Burlet, N., \& Cooper C. (2008). European guidance for the diagnosis and management of osteoporosis in postmenopausal women. Osteoporos Int.

12. Kucher, N., Zemtsov, M., \& Zarazovsky, M. (2006). Deformation of layered epoxy composites reinforced with high-strength fibers. Problems of Strength, pp. 41-57.

13. Nekhozhin, A. (2013). Bilayer mathematical model of human femur neck for the stress state research after reinforcement with different designs of implants. Herald of the Samara State Technical University, Vol. 3(32), pp. 129-135.

14. Savelieva, O., Prokopovich, I., Pavlyshko, A., Matveev, A., \& Starushkevych T. (2018). Computer modeling of implant for femur reinforcement. Proceedings of Odessa Polytechnic University, Vol. 1(54), pp. 51-61. 


\title{
Комп'ютерне проектування профілактичного зміцнення армованої шийки проксимальної стегнової кістки
}

\author{
Савельєва О. ${ }^{1}$, Старушкевич Т. ${ }^{2}$, Матвєєв А. ${ }^{3}$
}

${ }^{1}$ Південноукраїнський національний педагогічний університет ім. К. Д. Ушинського, вул. Старопортофранківська, 26, 65020, м. Одеса, Україна;

${ }^{2}$ Одеський національний політехнічний університет, просп. Шевченка, 1, 65044, м. Одеса, Україна;

${ }^{3}$ Новокуйбишевський міський центральний госпіталь, вул. Островського, 32, 446206, м. Новокуйбишевськ, Росія

Анотація. Перелом стегна є одним з найнебезпечніших переломів, оскільки він $є$ достатньо поширеним у літніх людей та важко піддається лікуванню. 3 огляду на загальноприйняту практику, найбільш ефективним способом лікування $є$ хірургічне втручання, але його результати на тлі остеопорозу не є задовільними. Зменшення імовірності переломів стегна є складним завданням, яке може бути вирішене лише шляхом об'єднання медицини і досліджень механіки деформованого твердого тіла. У цій роботі розглянуто розрахунок напружень, що виникають від впливу армованої шийки стегнової кістки під дією різних навантажень. На сучасному етапі дослідження проводяться розрахунки напружено-деформованого стану, що відповідають навантаженням від удару при падінні людини на стегно. Порівняння значень напружень свідчить про надійність використання розглянутих імплантатів, що у результаті зменшує імовірність перелому стегна. Використання армуючих металевих конструкцій у кістковій тканині призвело до збільшення найбільших допустимих значень приблизно на 140 \%, що підтверджує практичну цінність їх застосування. Таким чином, попередне зміцнення шийки стегнової кістки у людей похилого віку знижує імовірність руйнування унаслідок зменшення граничних напружень у небезпечних зонах.

Ключові слова: комп'ютерне моделювання, шийка стегна, числове моделювання, напружено-деформівний стан. 